\title{
Czeski Bóg? Religijność Czechów jako wynik tradycji społeczno-kulturowych ${ }^{1}$
}

Streszczenie: Celem artykułu jest prezentacja specyfiki czeskiego Kościoła i religijności Czechów. Autorka inspiruje się pracami głównie czeskich badaczy (Petr Fiala, Dana Hamplová, Tomáš Halík, Pavel Hošek, Jan Jandourek, Max Kašparů, Dušan Lužný, David Václavík, Michal Martinek, Zdeněk R. Nešpor, Pavel Říčan, Ivo O. Štampach, O. Štěch, David Václavík) i rozwija zawarte w nich myśli. Zajmuje się stereotypem Czecha, charakterystyką czeskiego wierzącego, czeskiego duchownego oraz czeskiego Kościoła, znajdując źródła wskazanych odmienności $\mathrm{w}$ wydarzeniach historycznych i ich interpretacji. W zakończeniu artykułu przedstawiono wnioski i przybliżono odbiorcy „obraz czeskiego Boga”.

Słowa kluczowe: czeska kultura, edukacja religijna, Bóg, wiara, religia, Kościół, Czesi

\section{Wprowadzenie}

Czeska kultura jest - jak każda inna - specyficzna, unikalna, jedyna w swoim rodzaju. Jeżeli w ogóle wypada mówić o cechach typowych dla pewnej niesprecyzowanej i mimo wszystko wyobrażeniowej zbiorowości, to o Czechach można zaryzykować twierdzenie, że są na ogół spokojni, powściągliwi w okazywaniu emocji, że wroga wolą wykpić, ośmieszyć, przemóc sprytem, niż atakować bronią, narażając własne życie; że są raczej konserwatywni, lubią przebywać w znanym im środowisku, wolne chwile spędzają w domu lub na działkach czy we własnych domkach letniskowych; że są zaradni, praktyczni i zręczni i wiele rzeczy potrafią zrobić lub naprawić sami (por. wyrażenie: zlaté české ručičky), mają zamiłowanie do porządku i dyscypliny i potrafią przetrwać w różnych trudnych sytuacjach życiowych. Jak wiadomo, osobowość człowieka jest po części wrodzona, po części - wynikiem przekazywania w procesie socjalizacji

1 Artykuł powstał w ramach realizacji projektu Uniwersytetu Ostrawskiego: Obraz sacrum v jazyce křest’anské mládeže, SGS04/FF/2019-2020. 
i edukacji odpowiednich wzorców zachowań. Analizując czeską religijność, mamy na uwadze oba aspekty wspomnianej osobowości.

Językoznawcy, szczególnie ci, którzy zajmują się etnolingwistyką, antropolingwistyką lub lingwistyką kognitywną, zdają sobie sprawę z tego, że niejeden klucz do kulturowej natury (kulturowości) członków grupy etnicznej ukrywa się w jej języku, w sposobie narracji, słownictwie, frazeologii, paremiach, dowcipach... Już co najmniej od czasów Humboldta uznaje się "zależność między językiem a kulturą za dwustronną" (Pajdzińska, 2010, s. 49). Tzw. integracjonizm w ujęciu Zelliga S. Harrisa, amerykańskiego językoznawcy, polega na tym, że społeczności etnicznej nie można poznać przez samą obserwację - konieczna jest znajomość jej języka (ojczystego). Język jest potwierdzeniem świata zewnętrznego, świadkiem życia człowieka; wszelkie myślenie teoretyczne nakłada się na znaczenie poszczególnych wyrazów (Patočka, 1992, s. 125), a charakter myśli zależy z kolei od języka, ponieważ człowiek nie myśli inaczej niż „pojęciowo”, werbalnie (Peregrin, 2014, s. 18). Nawet język nauki nie jest autonomiczny. Język zawsze współokreśla (determinuje, precyzuje) doświadczenia człowieka (Kajfosz, 2009), formując odrębne światy myślowe. Myślenie zatem jest zawsze myśleniem w pewnym języku (Schaff, 1967, s. 134). Zgodnie z tym założeniem w poniższym tekście często korzystamy z czeskich pojęć i nazw² .

Celem niniejszego tekstu jest przedstawienie - po kolei - czeskiego Kościoła, czeskiej religijności i „czeskiego Boga”. Na podstawie odpowiedniej literatury przedmiotu staramy się znaleźć odpowiedź na pytania: skąd się bierze odmienność czeskiego Kościoła i specyfika religijności czeskich wierzących. Interesuje nas, jak oni postrzegają sami siebie, jaki obraz Boga (świętości) wykreowali na podstawie przekazanych im informacji lub własnych doświadczeń.

\section{Swoistość czeskiego Kościoła}

Specyficzna sytuacja Kościoła w Republice Czeskiej jest efektem odmienności dziejów tego kraju, niepowtarzalnych uwarunkowań społecznych i politycznych. Podejmując temat, należy więc przytoczyć kilka istotnych wydarzeń historycznych, które spowodowały, że czeska religijność jest zdecydowanie antydoktrynalna, antyklerykalna, antyinstytucjonalna (antykościelna). Moż-

2 Używane w artykule czeskie wyrazy, jak również bardziej obszerne fragmenty czeskich tekstów zostały przetłumaczone przez autorkę. 
na ją nazwać, posługując się pojęciem przypisywanym brytyjskiej socjolog Grace Davie, wiarą bez przynależności lub - zgodnie z określeniem czeskich religioznawców - niekościelnym chrześcijaństwem, wyznawaniem Boga bez konfesyjnej afiliacji. Wydarzenia z przeszłości narodu czeskiego i ich interpretacje ukształtowały nie tylko stosunek Czechów do Kościoła, ale również ich tożsamość zbiorową (etniczną), kulturową i językową. Ukształtowały tzw. duży i mały czeski patriotyzm³ (por. Patočka, Hošek i inni) i przywiązanie raczej do mniejszych regionów (zemská identita) w typie niemieckich „landów"4, niż do państwa czeskiego w całości.

Wśród licznych źródeł historycznych, socjologicznych lub filozoficznych najbardziej cenne okazały się prace Hoška, Václavíka, Nešpora, Lužnego, Fiali i innych (por. Hošek, 2018; Václavík, 2010; Nešpor i Lužný, 2007; Fiala, 2007 i inni). Należy podkreślić ważne znaczenie nie tylko samych faktów historycznych, ale też ich wersji zmitologizowanej i przedstawianej w czeskiej twórczości literackiej lub filmowej, a przede wszystkim w ramach edukacji szkolnej. Zdaniem Pavla Hoška (2018, s. 98 i n.), nawiązującego do wcześniejszych prac Rudolfa Říčana oraz Karla Skalickiego (szczególnie zaś do jego tekstu Prolegomena k budoucí filosofii českých dějin, 1978), ważnym wydarzeniem było samo przyjęcie chrześcijaństwa z Bizancjum (w 863 r.) i jego adaptacja z jednej strony do warunków zachodniosłowiańskiego pogaństwa, z drugiej - do poprzedniej lub paralelnej działalności misjonarzy frankońskich. Chodziło o rzadką na terenach Słowiańszczyzny dwubiegunowość kulturowo-duchową, i to w bardzo odległym i kruchym okresie formowania się chrześcijaństwa wśród Słowian (Morawian).

Wschodnie poselstwo Cyryla i Metodego zostało stopniowo zastąpione przez czeski gotyk oparty na zachodnim katolicyzmie. Etap ten, nazywany świętowacławskim (svatováclavský katolicismus), nie jest oceniany zbyt wysoko, a odwoływanie się do chlubnej tradycji czeskiego chrześcijaństwa świętowacławskiego w okresie protektoratu (marzec 1939-maj 1945) „stało się objawem kolaboracji z rzeszą Hitlera" (Hošek, 2018, s. 107).

3 Mały patriotyzm jest patologiczny, egoistyczny, szowinistyczny (čecháčkovství); duży - wspaniałomyślny, ofiarny, godny naśladowania, korzystny również dla innych narodów, dla ludzkości w ogóle (češtství) (por. Hošek, 2018).

4 Sami mieszkańcy Czech odróżniają co najmniej Czechy historyczne (w języku czeskim Čechy lub vlastní Čechy) od Moraw, ew. Moraw i Śląska (Morava a Slezsko). Dodajmy, że nazwa Česko jest w użyciu od przełomu lat 1992 i 1993, tj. od podziału Czechosłowacji. 
Kolejną specyfikę czeskiego chrześcijaństwa dostrzega się w okresie tzw. czeskiej reformacji (husycko-braterskiej), poprzedzającej działalność Marcina Lutra, która rozpoczyna się męczeńską śmiercią Jana Husa, a kończy emigracją Jana Amosa Komeńskiego i która obejmuje późny okres aktywności Jana Žižki z Trocnova oraz ruch religijny Braci Czeskich inicjowany przez Petra Chelčickiego (Jednota bratrská). Również reformacja docierająca z Niemiec szybko rozpowszechniła się w środowisku czeskim. Umocniła egalitaryzm - nie tylko w sensie równości przed Bogiem, ale też w znaczeniu sekularnym, w ramach społeczeństwa. Pod tym względem reformacja przypominała sławne początki chrześcijaństwa na Wielkich Morawach i stała się wzorem dla późniejszej demokracji międzywojennego państwa czechosłowackiego. Reformacja była i jest symbolem postępu (por. hasło pokrokový odkaz české reformace), w odróżnieniu od konserwatywnego gotyku lub baroku. Jest synonimem sprawiedliwości i prawdy. Etap reformacji jest adorowany także przez filologów jako okres wykwintnej czeszczyzny (por. Biblię Kralicką lub prace językoznawcze Daniela Adama z Veleslavína; stąd określenie veleslavínská čeština). Ludności czeskiej prawdopodobnie odpowiadał ewangelicki etos pracy, nawoływanie do oszczędności, zapobiegliwości oraz podkreślanie takich cech ludzkich i wartości moralnych, z którymi Czesi chętnie się utożsamiali, podobnie jak z wyobrażeniem chrześcijanina jako człowieka pracującego (por. homo faber), a nie (tylko) świętującego i adorującego Boga (homo festivus).

Okres wojny trzydziestoletniej oraz kontynuowanej po jej zakończeniu rekatolizacji i germanizacji społeczeństwa zyskał miano czasów ciemności (doba temna), aczkolwiek nie chodziło o ewidentną ciemnotę i zacofanie. Powodu do generalnego potępiania Kościoła katolickiego za to, co działo się po przegranej bitwie na Białej Górze (1620), nie widzi ani przywołany powyżej Hošek (2018), ani wielu jego poprzedników, krytyków masarykowskiej linii interpretacji czeskiej przeszłości, którzy - przeciwnie - podkreślali korzystną dla kultury czeskiej działalność zakonu jezuickiego. Ten etap historyczny określa się często w historiografii jako drugi czeski gotyk, jako etap świętojański (svatojánský katolicismus) - ze względu na przebiegającą w tym czasie (1721) kanonizację Jana Nepomucena (†1393) - albo po prostu jako okres habsburski ${ }^{5}$.

5 Pamiętajmy, że pokrywa się on m.in. z okresem odrodzenia narodowego, mającym zdecydowanie antyhabsburski charakter, gdy Rzym był utożsamiany z Wiedniem i odwrotnie. 
Wrogość wobec monarchii austriackiej (antirakušáctvî) korespondowała z wrogością wobec Kościoła katolickiego, i to pomimo faktu, że niemało zaangażowanych w odrodzeniowy nurt społeczno-polityczny przedstawicieli inteligencji czeskiej było wyznania rzymskokatolickiego (np. Josef Dobrovský, Karel Havlíček Borovský, w odróżnieniu od ewangelików Františka Palackiego, szczególnie zaś Pavla Josefa Šafaříka czy Jána Kollára).

W tym samym duchu antyklerykalizmu ${ }^{6}$ formowało się społeczeństwo czeskie po uzyskaniu niepodległości w 1918 roku. Choć wśród ludności zdecydowanie przeważał katolicyzm, ówczesna elita polityczna na czele z prezydentem Masarykiem była zwolennikiem reformacji i wracała do antykatolickich myśli odrodzeniowych. Masaryk w tzw. czeskiej kwestii (česká otázka) wyrażał poglądy, których podstawą była idea czeskiego humanizmu obejmującego husytyzm, reformację i odrodzenie, z czym, jak już zauważono, nie zgadzali się wszyscy ówcześni czescy historycy. Głównym oponentem Masaryka reprezentującym czeską historiografię był Josef Pekař, z pozycji polityka atakował prezydenta Josef Kaizl ${ }^{7}$. Masaryk był przekonany o tym, że dla społeczeństwa jest korzystna pewna forma religijności, ale nie kościelne (klerykalne) chrześcijaństwo (Nešpor i Lužný, 2007, s. 24). Przykładem nawiązania do tradycji husyckich jest hasło Pravda vitězí, które widnieje na fladze prezydenckiej od 1918 roku do dziś. W omawianym okresie tzw. Pierwszej Republiki Czechosłowackiej powstał Kościół Czechosłowacki (Církev československá, 1920, nazwany w 1970 roku Kościołem Czechosłowackim Husyckim, Církev československá husitská) jako reformowany Kościół katolicki (liturgia przebiega od samego początku wyłącznie w języku ojczystym Czechów, celibat polega na dobrowolności, wyznawanie Boga zawiera pewne elementy Kościoła wschodniego), który pozyskał znaczną część dotychczasowych tradycyjnych (prawowiernych) katolików.

Zmiana ustroju w 1948 roku nie była aż tak przełomowym momentem z punktu widzenia czeskiej religijności (choć przyniosła zasadnicze zmiany ograniczające wolność wyznania i „odgórne” sterowanie sferą ideologiczną), ponieważ już pierwsze państwo czechosłowackie było mocno uprzemysłowione, klasa robotnicza tworzyła silną warstwę społeczną, a laicyzacja i ateizacja społeczeństwa były już wtedy zaawansowane. Według danych statystycznych w 1946 roku wiarę w Boga zadeklarowało ok. 80\% ludności, lecz

6 Ksiądz Josef Prokeš nazywa klerykalizm wypaczeniem (wykrzywieniem) wielkiego daru Boskiego, jakim jest kapłaństwo.

7 https://cs.wikipedia.org/wiki/Spor_o_smysl_českých_dějin (24.6.2020). 
regularnie praktykujących było w tym czasie tylko ok. 20\% (Václavík, 2010, s. 95).

Bezpośrednio po 1989 roku Kościół cieszył się w Czechosłowacji (później Republice Czeskiej) niebywałą popularnością. Duże znaczenie miały akt kanonizacji Anežki Czeskiej, wizyta papieża Jana Pawła II czy przedstawienie reszcie społeczeństwa duchowieństwa znanego tylko wąskiemu kręgowi dysydentów. Szansy na trwały sukces jednak Kościół nie wykorzystał. Powodów było więcej. Źródła z reguły podają, że ówczesny obraz Kościoła był znacznie wyidealizowany; dopiero z upływem czasu okazało się, że około 10\% księży współpracowało z tajną policją. Społeczeństwo nie popierało ani restytucji majątków kościelnych, ani ingerencji kardynała Miroslava Vlka w sprawy polityczne (wystąpienie pod koniec 1997 roku z żądaniem dymisji drugiego rządu Václava Klausa).

Mając na uwadze wspomniane powyżej czynniki, nie dziwimy się ocenie sytuacji Kościoła dokonywanej przez Czechów. W opinii Hoška, Kašparů i innych Czesi uważają, że Kościół nie powinien być ani zbyt bogaty, ani zbyt mocny. Ludzie na co dzień mają luźne relacje z Kościołem, może nawet odnoszą się do niego z sympatią jako do instytucji, która miałaby im pomóc w chwilach, gdy będzie im potrzebna. Oczekują, że Kościół będzie do dyspozycji na każde zawołanie (Hošek, 2012, s. 39), a jednocześnie nie będzie wymagał nic w zamian ${ }^{8}$. Zdaniem Kašparů Kościół w Czechach traktuje się jak wyrostek robaczkowy, o którym wiadomo, że jest coś takiego w organizmie państwa, ale gdyby go nie było, to też nic strasznego, a może nawet lepiej, bo czasami grozi zapaleniem i komplikacjami. Ten sam autor przyrównuje również Kościół do włosów na głowie - ich stratę można przeżyć, ale lepiej, gdy są, bo wtedy są ozdobą - chrztu, ślubu, pogrzebu... Zacytujmy jeszcze przyrównanie Kościoła do czułego nerwu: „zaboli, odezwie się za każdym razem, gdy dzieje się coś nieprawego" i jedynie ze względu na demokrację i zglobalizowaną metakulturę nie zaleca się jego usunięcia, „lecz tylko wyrafinowane, pełne i trwałe znieczulenie, anestezję" (Kašparů, 2008, s. 263). Posługując się aluzją do znanego hasła politycznego „socjalizm z ludzką twarzą", można na zakończenie stwierdzić, że właśnie takiego „ludzkiego” Kościoła poszukują Czesi.

8 Takie stanowisko charakteryzuje tytuł pracy Gillesa Lipovetzkiego w czeskojęzycznym tłumaczeniu: Zmierzch obowiązku. Bezbolesna etyka nowych czasów demokratycznych (Soumrak povinnosti. Bezbolestná etika nových demokratických časů). 


\section{Specyfika czeskiego (nie)wierzącego}

Religijność to nie tylko duchowość, spirytualność, numinosum. Istnieje wiele aspektów religijności. Jak zauważa Józef Bocheński (1998, szczególnie ss. 148-178), religijność jest wielopoziomowa. Nie chodzi tylko o stosunek do świętości, ale też o charakter odpowiedzi na pytania egzystencjalne, uznanie i szanowanie pewnych zasad moralnych, posiadanie odpowiedniego światopoglądu. Analogicznie do poprzedniego rozdziału pokusimy się obecnie o odpowiedź na pytanie, na czym polega typowy wizerunek czeskiego chrześcijanina, włączając w ten temat również autostereotyp Czecha. W pierwszej kolejności dokonujemy charakterystyki czeskiego nieteologa (laika), następnie księdza, korzystając z prac lub ustnych wypowiedzi szeregu doświadczonych badaczy i wrażliwych obserwatorów czeskiego społeczeństwa, z reguły socjologów, teologów, religioznawców, historyków, psychologów, psychiatrów, pedagogów.

O ile wcześniej symbolem Czecha był Szwejk (Švejk) Jaroslava Haška, który wybrał strategię wykręcania się sianem i obracania wszystkiego w żart, o tyle w drugiej połowie XX wieku stał się nim inny fikcyjny bohater, uniwersalny czeski geniusz, wszechstronnie uzdolniony artysta, a szczególnie dramatopisarz, Jára Cimrman9 który mógłby być rówieśnikiem Szwejka, gdyby jeden i drugi żyli naprawdę. Jára Cimrman inspirował wszystkich wokół siebie do przełomowych odkryć, miał wpływ na zasadnicze wydarzenia polityczne w cesarstwie austriackim przed pierwszą wojną światową, wiedział wszystko z wyprzedzeniem, sam jednak stał się ofiarą sceptycyzmu staromodnych rodaków i nieuzasadnionej krytyki.

Kolejne stereotypowe postrzeganie Czechów bazuje na ich niby-ateizmie. Jak słusznie zauważa Aniela Różańska, do czeskiej religijności podchodzi się ze znacznym uproszczeniem - ze względu na fakt, że jej przejawy są mało widoczne. A jednak „religijność czeska jest fenomenem dużo bardziej skom-

9 Postać tę wykreowali czescy aktorzy popularnego teatru (Divadlo Járy Cimrmana) po części zawodowego, po części amatorskiego, wystawiając sztuki napisane niby przez wspomnianego czeskiego geniusza. Niepowtarzalny humor tych komedii opiera się na autoironii i absurdalności. Jedna ze sztuk, nazwana „Czeskie niebo” (České nebe), jest parodią wyolbrzymianych zasług bohaterów z czeskiej przeszłości, np. świętego Wacława, głównego dowódcy baśniowych wojsk blanickich rycerzy czuwających pod wzgórzem Blaník w środkowych Czechach i gotowych - rzekomo - do obrony czeskiego narodu w chwili, gdy nastanie taka potrzeba. 
plikowanym i niepodlegającym jednoznacznej kategoryzacji” (Różańska, 2019, s. 41). Autorka rozwija tę tezę, dowodząc, że nie chodzi o zdecydowaną areligijność społeczeństwa czeskiego, lecz religijność odmienną, wyrażającą $\mathrm{w}$ inny sposób wiarę $\mathrm{w}$ transcendencję, rezygnującą (w większym stopniu niż np. w Polsce) z instytucji wyznaniowych. Społeczeństwo czeskie niewątpliwie należy do najbardziej zlaicyzowanych i bywa przyrównywane do Estończyków i Niemców z byłej RFN. Z ostatniego spisu ludności (2011) i innych miarodajnych źródeł wynika, że do wiary przyznaje się w Republice Czeskiej tylko ok. 14\% ogółu mieszkańców (z ok. 10 milionów Czechów niewiele ponad milion podało przynależność do Kościoła katolickiego, 192 tys. - do innych Kościołów). Istotne jest jednak to, że aż 45\% respondentów skorzystało z możliwości niepodawania żadnej odpowiedzi. Rozpowszechniony jest brak potrzeby deklarowania przynależności do konkretnego Kościoła, a pytanie o wiarę należy do podobnie niestosownych jak np. pytanie o wysokość dochodów. Warto dodać, że arkusze spisowe zawierały tylko jedno (nieobowiązkowe) pytanie na temat wiary. Istnieje nawet (naukowo raczej nieudowodniony) pogląd, że Czesi są dumni ze swojego ateizmu, lecz prawdziwych ateistów, przekonanych o nieobecności czegoś, co człowieka przerasta, także nie ma w Republice Czeskiej zbyt wielu - według oszacowania badaczy zdeklarowanych ateistów jest 8-30\% (Martinek, 2016, s. 16). „Nie uważam, że aż siedemdziesiąt procent ludzi u nas to ateiści," twierdzi Jaroslav Max Kašparů (2019, s. 33), „to, co u nas przeważa, nie jest niestety [podkreślenie I.B.] ateizmem, ale analfabetyzmem religijnym". Autor w ten sposób świadomie nawiązuje do popularnego wyroku znanego czeskiego teologa rzymskokatolickiego, Tomáša Halíka. Jego ocenę czeskiej spirytualności można ująć w następujące słowa: tradycyjnych wierzących (katolików lub protestantów) jest w Czechach niewielu; zaczyna dominować typ nonkonformistycznego (młodego) intelektualisty ze środowiska miejskiego, uważającego kwestię wiary za element kultury. Taki wierzący jest wymagającym (wobec Kościoła) i wybrednym „konsumentem” religijności, wiarę przyjmuje i wyznaje z zastrzeżeniami. Często używany „termin” Halíka „cosizm” (něcismus) trafnie charakteryzuje charakter religijności znacznej części społeczeństwa czeskiego: nie przynależę do żadnej grupy wyznaniowej i nie chodzę do żadnego kościoła, a jeżeli tak, to najwyżej na pasterkę, bo ogólnie lubię święta, a pasterka (pưlnoční mše) to piękna tradycja bożonarodzeniowa, podobnie jak liczne filmowe baśnie w świątecznym programie telewizyjnym. Nie wierzę jednak w uosobionego Boga i w różnych innych świętych, Biblii nie czytam, ale wierzę, że coś nade mną jest. 
Nawet wierzący Czesi z reguły nie manifestują swojej wiary w sposób okazały, spektakularny, czują niechęć wobec Kościoła jako instytucji oraz duchowieństwa i są uczuleni na próby manipulacji ze strony natrętnych ewangelizatorów, podobnie jak na bigoterię, wystawne i kosztowne imprezy kościelne. Obawiają się etykiety fanatyków, a za mocno obraźliwe uważają określenia pánbíčkář, pobožniostkár lub kostelní bába (pobożniś, świętoszek, dewotka). Kašparů (2013, ss. 101-102) odróżnia prawdziwą pokorę wobec Boga od „zgarbionej” pokory, upokarzania siebie w celu podkreślenia swojej cnotliwości (hrbatá pokora, sebepokořování). Wiara, nawet szczerze wierzących Czechów, jest - jak nazwał to Halík - spokojna, cicha, wstydliwa, płochliwa (plachá zbožnost). Halík wprowadził też do dyskusji na temat czeskiej religijności kolejne „słowa kluczowe”: apateismus (obojętność religijna), náboženská negramotnost, náboženský analfabetismus oraz náboženský diletantismu (por. Halík, 1997, ss. 49-51; 2018, s. 207).

O czym również należy pamiętać, opisując religijność Czechów, to różnorodność wyznań w tym państwie. Źródła podają, że oficjalnie rejestrowanych Kościołów i grup wyznaniowych jest ponad 40, w tym 15 autokefalicznych ortodoksyjnych Kościołów chrześcijańskich (szczegółowo można się o tym dowiedzieć np. z pracy Martinka, 2016 lub z Internetu - patrz strony internetowe podane w bibliografii do artykułu). Rejestracji Kościołów dokonuje się w odpowiednim dokumencie (Rejstř́k církví a náboženských společností) za pośrednictwem ministerstwa kultury, zgodnie z ustawą 3/2002 o Kościołach i grupach religijnych, po czym zarejestrowany podmiot staje się osobą prawną. Kościoły mają status organizacji niepaństwowej, niedochodowej. Do najbardziej znanych Kościołów, obok rzymskokatolickiego i greckokatolickiego, należą: Církev československá husitská, Českobratrská církev evangelická, Československá církev evangelická, Evangelická církev augsburského význání v České republice, Slezská církev evangelická augsburského vyznání, Apoštolská církev i inne. A każdy Kościół to (trochę) inna doktryna, inny sposób wyznawania wiary. Pomimo tego szerokiego wachlarza możliwości zdecydowana większość Czechów nie należy do żadnego Kościoła. Wynika to z faktu, że przeciętny Czech z reguły „nie rodzi się” do religijności (nie jest dzieckiem wierzących rodziców), religijność nie jest elementem jego tożsamości, wynikiem naturalnej socjalizacji w rodzinie. Nauka religii w szkołach państwowych należy do rzadkości. Czech przeważnie sam dojrzewa do religijności (por. np. Hamplová, 2013, s. 85) ${ }^{10}$.

10 Nawet księża i znani teolodzy czescy są konwertytami (por. Tomáš Halík lub Martina Viktorie Kopecká). 
Właśnie w poszukiwaniu własnej drogi do Boga można się dopatrywać źródła wielości odmian religijności Czechów. Max Kašparů (2008, s. 230) dokonuje podziału czeskich wierzących na kilka kategorii. Autor odróżnia „chodzących do kościoła" (chodiči), którzy uprawiają swoją codzienną religijność, nie zastanawiając się zbyt głęboko nad jej treścią. Drugą kategorię tworzą „pełniący obowiązki wobec Kościoła" (plniči), nieco niżej plasują się osoby pojawiające się w kościele raz w roku (jednoročáci - aluzja do nazwy młodego jelenia wynikająca z typowej, niedoskonałej rozbudowy poroża, po polsku szpicak), które znalazły się tam raczej przez przypadek, z reguły podczas Świąt Bożego Narodzenia. Kolejna grupa to tzw. chórzyści (kưrovci - dowcip polega na tym, że tak samo brzmi nazwa zoologiczna gatunku kornika dewastującego aktualnie lasy iglaste), których w dobry nastrój wprawia członkostwo w chórze lub inna forma zaangażowania w życie parafii. Istnieją też tzw. nieoczekiwani (nečekanci), którzy pojawiają się nagle i równie szybko znikają. Najbardziej smutną kategorię tworzą, zdaniem Kašparů, „wierzący na kółkach” (kolečkáři - tak potocznie nazywa się niepełnosprawnych, czyli osoby przemieszczające się na wózku inwalidzkim), którzy bądź wcale nie mają świadomości, że są w kościele (nie zjawili się tam z własnej woli), bądź trafili tam po raz pierwszy w życiu (np. na własny ślub), w każdym razie zostali tam „doholowani” przy pomocy jakiegoś pojazdu na kółkach - w wózku dziecięcym, w samochodzie wynajętym do ślubu lub należącym do zakładu pogrzebowego.

Wypowiedzi księży na temat czeskich wierzących wynikają z autopsji, z ich codziennego kontaktu z różnego rodzaju „gatunkami” laików. Posługując się po raz kolejny tekstem Kašparů, przytaczamy fragment jego niezbyt pochlebnej, ale niestety prawdziwej refleksji, kąśliwej parodii myślenia niejednego czeskiego katolika:

(...) jestem przecież wierzący, jestem katolikiem, bardzo dobrze wiem, jak to było z tym narodzeniem Jezuska obok tego osiołka w stajni..., wiem i to, że zmarł, a później ten jego trup się jakoś ocknął, czy jak to tam było, tego już dokładnie nie pamiętam..., ale poza tym o nim wiem wszystko. Również to, że w piątek nie powinno się jeść kiełbasy, a jak już ją zjem, to potem muszę w przyszłym roku powiedzieć o tym księdzu w tej drewnianej budce, co stoi tam w kościele. I tak tam o niczym innym już od lat nie gadam, bo innych grzechów nie mam. Nikogo nie zabiłem, nikogo nie okradłem, więc co tam będę z tym facetem ciągle rozmawiał. No i jeszcze coś: nabrałem młodych, bo poszedłem ochrzcić ich Józka [Pepíka], choć oni sobie tego nie życzyli. Do dziś nie wiedzą 
o tym, poprosiłem proboszcza, żeby im o tym - na wypadek, że się z nimi gdzieś kiedyś spotka - nie powiedział. Oni są co prawda oczywiście też mocno wierzący, w zeszłym roku byli na pasterce, bo my w domu jesteśmy wszyscy katolikami... (Kašparů, 2013, s. 36).

Przesada i lekkość zauważalna w języku wypowiedzi wcale nie lekceważy i nie profanuje tematu wiary. Wręcz przeciwnie - tego typu retoryka służy jako ostrzeżenie. Podobny apel słyszymy w ironicznej autorefleksji czeskich księży. Ogólnie stwierdza się, że dobrych kapłanów w Czechach brak, i to nawet katolickich, i że trudno przekonać kogoś do takiego zobowiązania (ślubów kapłańskich) na całe życie. Zdumiewająco problemem nie jest celibat, ale syndrom wypalenia. Od księdza wymaga się odpowiedniego wykształcenia, nieustannego poszerzania wiedzy i rozwoju duchowego, oczekuje się empatii, cierpliwości, ofiarności, panowania nad sobą itp. A chętnych do przyjmowania takiej postawy nie starcza. Zresztą, młodzi ludzie nie mają okazji nauczyć się takiego zachowania. Poza wyjątkami nie ma już dziś wielodzietnych rodzin, które Kašparů (2008, s. 198) nazywa miniaturowymi seminariami teologicznymi, w których skromność i uwzględnianie potrzeb rodzeństwa jest zjawiskiem naturalnym. Księża nieustannie narażają się swoim niezadowolonym wierzącym i/albo zwierzchnikom, muszą podejmować niełatwe decyzje: udzielają ślubu ludziom, którzy są ewidentnie niewierzący, dokonują chrztu, wiedząc, że rodzice przystępują do tego obrzędu jako do kultu pogańskiego, który ma zapewnić ich dzieciom łaskę „sił wyższych”, a z drugiej strony powinni zabiegać o przychylność społeczeństwa. Wykonują posługę rutynowo, zaspakajając „duchowe potrzeby ludu” (spirituální potřeby lidu, Kašparů, 2008, s. 190, 192), stają się „religijnymi rzemieślnikami” (nábožensští řemeslníci, Halík, 1997, s. 204), „producentami liturgii” (liturgičtí výrobci, Kašparů, 2019, s. 134), by w końcu się przekonać, że ludziom księża właściwie nie są potrzebni, że nie ma zainteresowania ich „towarem”. Lekceważy się ich jak domokrążców z garnkami tupperware: ten wasz produkt jest do niczego, mamy już kilka takich w piwnicy (Hadjadj, 2016, s. 19). W czasach ogólnego „triumfu egoistycznego indywidualizmu nad etyką obowiązku, solidarności i poświęcenia" (Hošek, 2012, s. 69), w czasach religijności rozumianej jako aktywność wolnoczasową „kultura ofiary i obowiązku jest martwa” (Lipovetsky, 2011, s. 64). Modna parareligijna spirytualność, jak zauważa Pavel Hošek (2012, s. 33), jest bardziej groźna niż ateizm z prawdziwego zdarzenia. Prymitywny szczep dzikusów w konfrontacji z ewangelią „gdy pożre kilku misjonarzy, stwierdzi, że w końcu lepiej nadawali się do słuchania niż jedzenia, 
i wysłucha, co mają do powiedzenia. Z sekularyzowanym chrześcijaninem jest o wiele gorzej - sądzi, że wie (...), więc już dalej nie słucha. Najgorsza niewiedza to nie ta prymitywa (...), gorsza jest [niewiedza - uzupełnienie I.B.] niedouka, który myśli, że wie (...)” (Hadjadj, 2016, s. 19).

Pod tym względem nie różnią się Czesi od innych sąsiednich postmodernistycznych lub raczej postsekularnych społeczeństw. Również czescy badacze (Hošek, Kašparů, Halík i inni) zauważają fakt, że ludzie, szczególnie młodzi, nie są zainteresowani holistyczną religijnością, przyjmowaniem konkretnej, gotowej religii w całości (pakietu ideologii). Nauczyli się zachowywać jak przy szwedzkim stole - z wszystkiego biorą po trochu: z chrześcijaństwa - ślub kościelny, z buddyzmu - uszanowanie każdego życia; korzystają z metod medycyny wschodniej, uprawiają jogę, uczą się medytacji, czytają literaturę ezoteryczną lub horoskopy. Ze względu na fakt, że przedmiotem sakralizacji (kultu) staje się sama konsumpcja, „konsument artykułów duchowych występuje w roli klienta, który zamawia i kupuje produkty religijne od najróżniejszych dostawców na podstawie szerokiego marketingu, obmyślonych public relations, jednym słowem - na zasadach wolnego rynku" (Hošek, 2012, s. 76), a odwiedzanie hipermarketów stało się najmocniejszym estetycznym i emocjonalnym przeżyciem tygodnia (Hošek, 2012, s. 74).

Za korzystną można uważać nieobecność w Republice Czeskiej monopolu Kościoła rzymskokatolickiego i wielość innych konfesji, co umożliwia Czechom zapoznanie się z wieloma ciekawymi przedstawicielami innych Kościołów. Wielką popularnością cieszy się obecne np. pastor kościoła husyckiego (Církev československá husitská), Martina Viktorie Kopecká, młoda, sympatyczna, wykształcona kobieta o wyjątkowej urodzie, która zanim wybrała się na studia teologiczne, pracowała w międzynarodowej korporacji. Dzięki własnemu zaangażowaniu, ale też znajomości kilku języków obcych, od 2014 roku zajmuje stanowisko przewodniczącego jednej z komisji Światowej Rady Kościołów. Wspomnieć należy również Alexandra Fleka, czeskiego teologa ewangelickiego i pedagoga, uczestniczącego od lat w projekcie Biblia XXI, autora popularnej Parabiblii, która ukazała się po raz pierwszy w 2018 roku i została napisana z myślą o najmłodszym pokoleniu niekoniecznie wierzących Czechów. Potrzebę kreowania innego obrazu Kościoła ułatwiającego działalność duszpasterską wśród młodzieży zauważyło dwóch youtuberów i równocześnie pastorów ewangelickich (Jakub Malý i Karel Müller), należących do Kościoła braterskiego (Československá církev bratrská), którzy sami siebie nazywają Pastoral Brothers i którzy w krótkich filmikach w dostępnej i dowcipnej formie przekazują widzom konkretne treści biblijne (religijne), 
nie oszczędzając ani najwyższych przedstawicieli życia politycznego, ani własnego środowiska religijnego. Używany przez nich język jest - podobnie jak w wypadku wspomnianej Parabiblii - świeży, zrozumiały, aktualny. W towarzystwie właśnie takich nietuzinkowych księży znalazł się m.in. popularny w Czechach Zbigniew Czendlik, pochodzący z Dębowca, absolwent studiów teologicznych w Katowicach i Warszawie, który z polskiej, chorzowskiej parafii został w 1992 roku skierowany najpierw do Náchoda, później do Lanškrouna. Jego refleksja na temat czeskiej religijności z perspektywy polskiego duchownego jest niezwykle cenna, a opublikowana w 2016 roku obszerna rozmowa, którą przeprowadziła z Czendlikiem Markéta Zahradníková i która niesie tytuł Postel [łóżko], hospoda, kostel, od razu stała się na czeskim rynku księgarskim bestsellerem.

Trzeba mieć na uwadze, że wielu czeskich duchownych, szczególnie medialnie znanych, nie wykonuje tylko tego jednego zawodu. Na przykład Jaroslav Max (Maximilián) Kašparů jest greckokatolickim księdzem, lekarzem (psychiatrą), pedagogiem, oprócz tego jest żonatym mężczyzną, ojcem dwóch dorosłych córek, pisarzem, autorem prac naukowych i popularyzujących naukę. Dawne rygorystyczne komunistyczne zasady wychowywania młodej generacji Czechów w duchu ateistycznej filozofii marksistowskiej spowodowały, że wielu późniejszych księży skończyło pierwotnie inne kierunki studiów, ma więc wiedzę z różnych dziedzin nauki. Księża są równocześnie teologami i historykami, filozofami, socjologami, psychologami, biologami, językoznawcami lub literaturoznawcami. Przerwanie ciągłości tradycji religijnej, nieobecność nauki religii w szkołach (ponieważ szkoła uczy wiedzy naukowej, a religia jest „nienaukowa”), potępianie uczestniczenia w niedzielnych nabożeństwach i ograniczanie możliwości kształcenia na wyższych szczeblach systemu edukacyjnego $\mathrm{w}$ przypadku młodzieży z rodzin wierzących przyczyniło się do tego, że nawet dziś, po 30 latach od zmiany ustroju, zdarza się, że na studia teologiczne decydują się osoby, które wcześniej nie miały z Kościołem nic wspólnego. Osoby te kończą studia pomyślnie i z powodzeniem wykonują swoją posługę duszpasterską. Być może paradoksalnie, ze względu na własną „ateistyczną” przeszłość, ich doświadczanie Boga (świętości) jest bardziej autentyczne i bardziej szczere, ponieważ nie niesie znamion przekazanej, zmodyfikowanej przez rodziców lub dziadków religijności „domowej”, łącznie z wynoszonymi z domu „karykaturami Boga” (patrz poniżej). Należy dodać, że obecnie wychowanie religijne w szkołach państwowych nie jest obowiązkowe, a ustawa o szkolnictwie (561/2004) umożliwia wprowadzenie nauki religii do programu zajęć szkoły, gdy jest w niej co najmniej siedmioro chęt- 
nych uczniów. O obowiązkowym lub nieobowiązkowym charakterze przedmiotu w średnich szkołach wyznaniowych ${ }^{11}$ (církevní školy) decyduje organ zarządzający ${ }^{12}$. Kończąc to opracowanie, pragnę nadmienić, że zarówno do Kościoła, jak i religijności Czechów (i nie tylko) odnosi się zarzut, że ma on/ ona charakter bardziej kobiecy, że brak w nim/niej elementu męskiego. Na temat żeńskiej i męskiej formy religijności wypowiada się aktualnie najmłodszy czeski biskup Tomáš Holub: „Kościół w wielu aspektach przyswoił sobie kobiece sposoby religijności na niekorzyść męskich" (Holub i Veselovský, 2017, s. 87). Księży dotyczy celibat, oczekuje się, że zachowują niewinność, że nigdy się z nikim nie pobiją, wiadomo także, że są pacyfistami - unikają służby wojskowej itp. Nie mogąc użyć przemocy fizycznej, uciekają się często do kokieterii lub intryg. Prawdziwy mężczyzna, zdaniem Holuba, nie grzeszy, ponieważ nie podoba mu się sama istota grzechu. „Raz ubił z Bogiem interes, że nie zgrzeszy, i dotrzymuje słowa” (s. 92). Mężczyzna widzi Boga wielkiego i chętnie mu służy, zachowując własną godność.

\section{Odmienność czeskiego Boga}

Do znanego powiedzenia, że Bóg stworzył człowieka, a człowiek - religię, można dodać inne: stworzony przez Boga człowiek stara się wtórnie wymodelować Boga na swój sposób. Odmienność wizji Boga wiąże się z omówioną specyfiką Kościoła i religijności. Jeżeli inny jest Czech, inne jest jego życie duchowe, inne są wyznawane przez niego wartości, to - zgodnie z logiką - inaczej wygląda także jego Bóg. Użytego w tytule określenia „czeski Bóg” nie rozumiem dosłownie. Zdaję sobie sprawę z tego, że użycie takiego sformułowania nie jest poprawne naukowo, a tym bardziej teologicznie. Moim zamiarem jest, po pierwsze, nawiązać do lekkiego tonu powyższych wypowiedzi autorów na poważne i trudne tematy religijne, po drugie, zilustrować poczucie humoru Czechów, które przejawia się także w ich obrazie Boga.

11 W Republice Czeskiej prowadzą działalność również podstawowe, średnie, specjalne lub artystyczne szkoły dla młodzieży chrześcijańskiej, niekoniecznie katolickiej. Założyć taką szkołę może zgodnie z ustawą o szkolnictwie - państwo, gmina, rejestrowany w Czechach Kościól, osoba prawna lub fizyczna. Zgodnie z nowelizacją ustawy największe kompetencje ma w tym wypadku wojewódzki urząd szkolny, który zarządza tymi szkołami (więcej na ten temat: spravni.juristic.cz/489621/clanek/ spravni2.html).

12 Co ciekawe, $w$ Czechach można zdawać $\mathrm{z}$ religii egzamin maturalny, nawet gdy przedmiot był nadobowiązkowy. 
Praktyczni Czesi wykreowali sobie Boga, który spełnia ich oczekiwania. Nieprzypadkowo została opublikowana nieduża, ale ciesząca się powodzeniem książka Kateřiny Lachmanovej Karikatury Boha (2014), rozwijająca wątek podjęty przez Karla Frielingsdorfa (Dämonische Gottesbilder, 1992; czeskie tłumaczenie 1995) lub Tilmanna Mosera (Gottesfergiftung, 1976). Oprócz tradycyjnych wyobrażeń Boga i Jego stosunku do człowieka, o których wspomniał już Frielingsdorf, czeska teolog przytacza kolejne, które najbardziej odpowiadają współczesnym Czechom. Należą do nich następujące: Bóg - amorficzna energia kosmiczna; Bóg - „miłośnik przyrody o duchowym wymiarze”, Bóg - „wellnes centrum” (służący dla przyjemności i regeneracji); Bóg - kumpel (całkiem niegroźny ziom, z którym można pogadać przy piwie, ale którego łatwo wyprosić za drzwi, gdy nie jest potrzebny). Nacisk na preferowaną przez Czechów wygodę i spokój pojawia się i w ambitniejszych pracach, np. Maxa Kašparů (2019). Jego zdaniem nie powinno się przeceniać roli Boga karcącego człowieka za popełniony grzech ani samego popełniania grzechu (hříchocentrismus, hříchotaxe). Zamiast myśleć o grzechu i karze, trzeba skupić uwagę na Chrystusie (kristocentrismus, kristotaxe), na Jego wspaniałomyślności ${ }^{13}$. A jeżeli Bóg ześle na nas cierpienie, należy je wykorzystać jak kapitał i zainwestować w siebie, w swój dalszy rozwój duchowy (Kašparů, 2019, s. 97).

\section{Wnioski}

Wracając do postawionych na wstępie pytań (Dlaczego czeski Kościół jest specyficzny? Skąd się bierze odmienna religijności Czechów? W jakiego Boga wierzą Czesi?), postaramy się podsumować najbardziej istotne spostrzeżenia.

Społeczeństwo czeskie, aczkolwiek mocno zlaicyzowane, nie jest i nie może być całkowicie ateistyczne, choćby z tego powodu, że znajduje się i rozwija w kręgu kulturowym zbudowanym na wartościach chrześcijańskich. Formy i metody wychowania socjalistycznego pozostawiły tu co prawda bardziej trwałe ślady niż np. mniej radykalny komunizm w Polsce, niemniej Kościół jako instytucja nigdy nie cieszył się zbyt wielkim szacunkiem. Społeczeństwo

13 Obraz Boga-dżentelmena jest dosyć częsty, a naśladowanie Chrystusa ma działać terapeutycznie. Dobremu nastrojowi i zadowoleniu z siebie sprzyja obraz Boga, który nie porównuje nas z innymi, być może lepszymi chrześcijanami. Wiary nie da się zmierzyć żadnym „wiarometrem” (věroměr, Kašparů, 2018) i nic dziwnego, że nie można jej ująć nawet w sposób naukowy, np. w badaniach socjologicznych, w spisach ludności (Hamplová, 2013). 
miało i nadal ma tendencję darzyć zaufaniem postacie z własnej reformacyjnej, „heretycznej” przeszłości (kacířská minulost), darząc ich sympatią, pomimo tego, że naukowa historiografia krytycznie oceniła niejeden ich skutek. Ze względu na wspomnianą zmitologizowaną interpretację czeskiej historii, której nawet obecna edukacja szkolna raczej nie kwestionuje, Czesi nadal częściowo tkwią w pogaństwie, a proroctwa przedhistorycznej księżniczki Libušy, córki legendarnego Kroka, skłonni są uważać za coś świętego. Także ten aspekt czeskiej tożsamości należy wziąć pod uwagę, ponieważ „podzielany obraz przeszłości jest w pewnym sensie »tworem kulturowym «" (Hošek, 2018, s. 91).

Naprzemienne wyznawanie prawd Kościoła ewangelickiego, które bardziej odpowiadały kulturowej naturze mieszkańców ziem czeskich, i katolickiego oraz utożsamianie tego drugiego z represjami ze strony Habsburgów można uważać za źródło nieustannych poszukiwań własnego sposobu „uprawiania” religijności. Wspomnieć należy również o wielowiekowej koegzystencji Czechów z żywiołem żydowskim (używającym z reguły języka niemieckiego), która skłania do dostrzegania zbieżności historii Czechów z losem utrapionego ludu izraelskiego.

W wyniku zasadniczych zmian wyznaniowych i ideologicznych w przeszłości współczesny Czech, bez względu na deklarowaną przynależność wyznaniową, jest po trosze protestantem, po trosze katolikiem, a po trosze mniej lub bardziej duchowym ateistą. Podążanie za prawdą i tolerancja wobec innych „poszukiwaczy” (hledači pravdy) jest w miarę stałą cechą czeskiej religijności. Poszukiwanie to niekoniecznie oznacza bezradność, wręcz przeciwnie - świadczy o chęci zrozumienia istoty rzeczy i o poczuciu odpowiedzialności za wyznawaną ideologię, o uszanowaniu indywidualności każdego człowieka oraz niechęci do udzielania uniwersalnych rad i wskazówek innym osobom.

Wizerunek Boga jest u Czechów raczej niesprecyzowany; Bóg przejawia się w przyrodzie, w energii kosmicznej, w aktywności ludzkiej; Jego miejsce nie jest wyznaczone obwodem murów kościoła. Bóg, zdaniem większości Czechów, przynajmniej tych, którzy w Niego wierzą, nie lubi i nie oczekuje częstego ani hucznego świętowania, okazałości, teatralności. Czesi są tradycyjnie amatorami „małych form scenicznych”, bawią się słowami. W podobny subtelny i kameralny sposób mówią o Bogu i do Boga. Na podstawie podanych interpretacji Czesi stworzyli sympatyczny, ale nieco infantylny obraz Boga, który grzechów ludzkich nie bierze do siebie, jest pogodny, koleżeński, wyrozumiały i wielkoduszny. Przyjmowanie takiej postawy wobec Boga 
jest z pewnością komfortowe w czasach, gdy w życiu człowieka nic złego się nie dzieje, w odwrotnym przypadku jest źródłem niepewności, zwątpienia lub lęku, ponieważ - jak trafnie zauważył Lipovetsky (2008, s. 73) - człowiek równy Bogu jest bezbronny. Bardziej korzystne dla Czechów okazuje się natomiast przekonanie, że Bóg wymaga od człowieka współpracy, a nie biernego oczekiwania Bożej łaski. Z tym prawdopodobnie wiąże się nie tylko pracowitość i oszczędność Czechów, ale i dbałość o zdrowie, kondycję fizyczną, sprawy finansowe czy bezpieczeństwo socjalne.

\section{Bibliografia}

Bocheński, J. i Parys, J. 1992. Józef Bocheński. Między logika a wiara. Warszawa: Noir Sur Blanc.

Czendlik, Z. i Zahradníková, M. 2016. Postel, hospoda, kostel (Zbigniew Czendlik). Praha: Argo.

Fiala, P. 2007. Laboratoř sekularizace (Náboženství v ne-náboženské společnosti: český prípad). Brno: Centrum pro studium demokracie a kultury.

Flek, A. 2019. Parabible (Tisková zpráva o našem prezidentovi Ježíši z Nošovic). Praha: Biblion.

Frielingsdorf, K. 1995. Falešné představy o Bohu (jejich vznik, odhalení a překonání). Kostelní Vydří: Karmelitánské nakladatelství.

Hadjadj, F. 2016. Jak dnes mluvit o Bohu? (Evangelizační anti-pomůcka). Brno: Centrum pro studium demokracie a kultury.

Halík, T. i Jandourek J. 1997. Tomáš Halík. Ptal jsem se cest. Praha: Portál. Halík, T. 2018. Doslov. W: Beck, U. Vlastní Bůh (Mírotvorný a násilnický potenciál náboženství). Praha: Karolinum, ss. 205-208.

Hamplová, D. 2013. Náboženství v české společnosti na prahu třetího tisíciletí. Praha: Karolinum.

Holub, T. i Veselovský, M. 2017. Biskup na snowboardu. Praha: Vyšehrad. Hošek, P. 2012. A bohové se vracejí (Proměny náboženství v postmoderní době). Jihlava: Mlýn.

Hošek, P. 2018. Je to náš príběh (Teologický esej o vlastenectví a křest’anských hodnotách české kultury). Brno: Centrum pro studium demokracie a kultury.

Kajfosz, J. 2009. Magia w potocznej narracji. Katowice: UŚ.

Kašparů, M. i Paulas, J. 2008. Do výšky volím pád. Kostelní Vydří: Karmelitánské nakladatelství. 
Kašparů, M. 2013. Po provaze ke Kristu. Kostelní Vydří: Karmelitánské nakladatelství.

Kašparů, M. i Ližičiar, M. 2018. Jaroslav Max Kašparů. Nebudu hrát divadlo pred Boží tvárí. Bmw: BeneMedia.

Kašparů, M. 2019. Rozhovory pod věží. Brno: Cesta.

Lachmanová, K. 2014. Karikatury Boha. Praha: Karmelitánské nakladatelství.

Lipovetský, G. 2008. Éra prázdnoty (Úvahy o současném individuu). Praha: Prostor.

Lipovetsky, G. 2011. Soumrak povinnosti (Bezbolestná etika nových demokratických časů). Praha: Prostor.

Martinek, M. 2016. Přehled křest’anských církví a jejich aktivit v $\check{C} R$. Praha: Portál.

Nešpor, Z. i Lužný, D. 2007. Sociologie náboženství. Praha: Portál.

Pajdzińska, A. 2010. Czy „zaklęty krąg języka” można przekroczyć? W: Pajdzińska, A. i Tokarski, R. red. 2010. Relatywizm w języku i kulturze. Lublin: UMCS Wydawnictwo Uniwersytetu Marii Curie-Skłodowskiej, ss. $43-57$.

Patočka, J. 1992. Přirozený svět jako filozofický problém. Praha: Edice Orientace.

Peregrin, J. 2014. Jak jsme zkonstruovali vlastní mysl. Praha: Dokořán.

Prokeš, J. 2019. Pán se stará. Praha: Portál.

Różańska, A. 2019. (A)religijność po czesku - ateizm, analfabetyzm religijny czy coś więcej? Edukacja Międzykulturowa. 1 (10), ss. 38-54.

Schaff, A. 1967. Jezzyk a poznanie. Warszawa: PWN.

Štampach, I.O. 2000. A nahoře nic (O možnostech postmoderního člověka žít duchovně). Praha: Portál.

Václavík, D. 2010. Náboženství a moderní česká společnost. Praha: Grada.

\section{Źródła internetowe}

https://cs.wikipedia.org/wiki/Seznam_církví_a_náboženských_společností_v_Česku (15.5.2020).

http://www3.mkcr.cz/cna_internet (15.5.2020).

https://www.cirkev.cz/cs/aktuality/190920nabozenska-vychova-ve-skolach-v-evrope (15.5.2020).

https://cs.wikipedia.org/wiki/Spor_o_smysl_českých_dějin (24.6.2020). spravni.juristic.cz/489621/clanek/spravni2.html (24.6.2020). 


\title{
The Czech God? Religiousness of Czechs as a result of sociocultural traditions
}

\begin{abstract}
The aim of the article is a presentation of special traits of the Czech Church life and the religiosity of Czechs. The author has been inspired by works of mainly Czech scholars (like Petr Fiala, Dana Hamplová, Tomáš Halík, Pavel Hošek, Jan Jandourek, Max Kašparů, Dušan Lužný, David Václavík, Michal Martinek, Zdeněk R. Nešpor, Pavel Říčan, Ivo O. Štampach, O. Štěch, David Václavík) and develops their ideas. Those ideas concern mainly the stereotype of a Czech, character of a Czech believer and a priest, as well as the Czech Church. The author explains specific traits of those ideas in the historic context of events and their interpretations. The article sums up with a conclusion and a presentation to the reader of a picture of the "Czech God".
\end{abstract}

Keywords: Czech culture, religious education, God, belief, religion, church, Czechs 